\title{
Bilateral Investment Treaties - a Potential Trap for Developing Economies: A Lesson from Thailand
}

\author{
By Robert Brian Smith ${ }^{*}$ \\ Nucharee Nuchkoom Smith ${ }^{\dagger}$
}

\begin{abstract}
There is a growing concern amongst both developing and developed countries concerning the potential impact of Investor-State Dispute Settlement (ISDS) awards on the ability of a government to act in the best interest of its citizens. ISDS clauses are included in Bilateral Investment Treaties (BITs) and increasingly, but not always, in Free Trade Agreements (FTAs). The potential impacts on the ISDS clauses may considerable and affect the decision-making ability of the government. Unfortunately, the government officers making those decisions may not be aware of the potential conflict with the requirements of a BIT or FTA. This paper focuses on the litigation between Walter Bau AG (in liquidation) and the Government of Thailand in relation to a concession agreement to design, construct, operate and maintain the Don Muang Tollway in Bangkok. Walter Bau alleged the lack of Fair and Equitable Treatment (FET) in relation to its investment due to the Thai government reducing tolls; continuing to improve roads in the vicinity of the toll road thus affecting traffic volumes and subsequently closing the Bangkok International Airport at Don Muang. Arbitral proceedings were conducted in Switzerland and resulted in a significant award to Walter Bau which was unsuccessfully challenged by Thailand. It describes the circumstances that led to the government's actions and the lessons that have been learnt from them. It also discusses how these issues have been addressed in Investor State Dispute Settlement in recent Free Trade Agreements entered into by Thailand and its trading partners, including Australia. Walter Bau provides a significant lesson for government's developing Public Private Partnership (PPP) projects which can have multiple investors at both the construction and operations stages. These investors are often foreign companies who have no other interest other than the return on capital from their investment.
\end{abstract}

Keywords: Walter Bau AG (in liquidation), investor-state dispute settlement, public private partnership, free trade agreements, bilateral investment treaties.

\section{Introduction}

Investor-state dispute settlement clauses are becoming a common feature of International Investment Agreements (IIAs) and Bilateral Investment Treaties (BITs). Increasingly they are being incorporated into Free Trade Agreements (FTAs). Initially the ISDS provisions provided limited protection to state parties

\footnotetext{
*International Development Assistance Consultant \& Independent Consultant/Adviser, Macquarie Centre, Australia.

${ }^{\dagger}$ PhD Graduand, School of Law, Western Sydney University, Parramatta Campus, Australia.
} 
but more recent agreements have included restrictions that preclude investors from seeking redress for government decisions concerning the health and welfare of their citizens. As will be seen later in this paper such clauses may exclude government decisions made to protect the environment, protect citizens from harm and to provide affordable health care.

Of particular concern to the authors is the potential risk to governments of officials unknowingly making decisions without realizing that the decisions may impact international investors who are able to seek compensation under a BIT, FTA or IIAs. They may not even know that such instruments exist! Forewarned they can ensure that contracts provide fair and equitable treatment to both parties. They can also ensure that where an ISDS process is initiated the officials are well versed in the process to be followed.

This paper is a case study and focusses on the Walter Bau ISDS case in Thailand and the lessons to be learned; and their implications for both developing and developed countries. Cases such as Walter Bau have lead nations to reconsider the content of ISDS provisions, particularly in FTAs.

\section{Literature Review}

Overview

Thailand is a developing country which is very active in improving its transport infrastructure. At the same time Thailand is enthusiastically negotiating FTAs. As a result Thailand allows foreign companies to develop its infrastructure within the framework of international trade rules.

Thailand has a mixed record in relation to implementation of Public Private Partnership (PPP) transport projects (see World Bank \& Ministry of Construction, Japan 1999a,b and Asian Development Bank 2000: Appendix 1-23). A World Bank Report has identified a number of reasons for this including overlapping responsibilities among responsible public agencies, lack of transparency in the bidding process, uncertainty about contract provisions including in relation to toll rate adjustments and toll free alternative routes, inconsistency between concession contracts and Thai law; and the need to adhere to established international dispute settlement procedures (World Bank \& Ministry of Construction, Japan 1999a, b).

In fact, Thailand's first and only Investor State Dispute Settlement (ISDS) case involved a transport project (Mangklatanakul 2010).

Thailand's exposure to ISDS cases is amplified by the fact that over the last few years Thailand has been enthusiastic about signing Free Trade Agreements (FTAs) and Bilateral Investment Treaties (BITs) (Mangklatanakul 2010: 85). 


\section{Treaty between the Kingdom of Thailand and the Federal Republic of Germany}

The BIT between Thailand and Germany is a fairly standard BIT and covers state-state (art 9) and investor-investor (art 9) dispute resolution. The Treaty only covers investments that have been approved in writing (art 2(2)). This is the only restriction that applies unlike the more recent FTAs signed by Thailand which are discussed below.

The investor or the state can initiate arbitration (art 10) with the parties agreeing on the members of the tribunal (art 10(2)). In the absence of other arrangements either party may request the President of the Court of International Arbitration of the International Chamber of Commerce in Paris to appoint the tribunal members art 10(2).

Investor State Dispute Settlement (ISDS) in FTAs involving Thailand and its Trading Partners

The development of ISDS mechanisms in bilateral and multilateral free trade agreements up to 2012 has been discussed in detail by Sappideen and $\mathrm{He}$ (2012). Little has changed over the last five plus years but there appears to be greater concern in the international community about the inclusion of ISDS mechanisms in FTAs (see Wilkins 2014). The potential impact on a country whether developing or developed could be very significant.

Thailand is party to six FTAs which include ISDS clauses as well as the ASEAN Comprehensive Investment Agreement. It is proposed to discuss them chronologically to review the evolution of ISDS clauses.

The Thailand-Australia Free Trade Agreement (TAFTA) restricts ISDS to "investors' management, conduct, operation and sale or other disposition of covered investments" (art 906). It excludes subsidies or grants to domestic investors and investments (art 902(1)), and procurement of government goods and services not for commercial uses (art 902(2). The Thailand New Zealand Closer Economic Partnership Agreement has similar provisions (art 9.3). Like the other two FTAs, the Japan Thailand Economic Partnership Agreement (JTEPA) restricts ISDS to the activities required by an investor to manage its investment (art 106(15)(c)).

ASEAN $N^{1}$-Australia-New Zealand Free Trade Area (AANZFTA) defines an investment as "being every kind of asset owned or controlled by an investor" (ch 11 art 2). It gives examples including movable and immovable property, shares, bonds and debentures, intellectual property rights, claims to money, business concessions required to conduct economic activity, and, of particular interest to this paper, "rights under contracts, including turnkey, construction, management, production or revenue-sharing contracts" (ch 11 art 2). The later clause is clearly directed to PPP projects. Such covered investments have access to the ISDS provisions (ch 11 art 18). Exclusions are national treasures

\footnotetext{
${ }^{1}$ Association of Southeast Asian Nations (ASEAN) member states are Brunei Darussalam, Cambodia, Indonesia, Lao PDR, Malaysia, Myanmar, Philippines, Singapore, Thailand and Viet Nam.
} 
and creative arts of national value; as well as security exemptions (ch 15 art 1(4)). Additionally, Thailand will deny benefits to an investor who is juridical person from a non-Party to AANZFTA (ch 11 art 11(2)).

Whilst AANZFTA had a relatively minor tightening with the exclusion of national treasures and creative arts of national value, the agreements which followed were significantly more restrictive.

The ASEAN Comprehensive Investment Agreement (ACIA), to which Thailand is a party, has extensive exemptions (art 17). It provides exemptions necessary to protect public morals or to maintain public order; to protect human, animal or plant life or health; and secure compliance with laws or regulations in relation to prevention of deceptive and fraudulent practices; protection of privacy; and safety. It also aims to ensure equitable imposition and dissemination of direct taxes and protect national treasures of artistic, historic or architectural value. It also allows countries to restrict exports of exhaustible natural resources. It also includes a security exemption (art 18).

The ACIA provisions became a template for the text of the individual Agreement [s] on Investment under the Framework Agreement on Comprehensive Economic Cooperation entered into by ASEAN with China, Korea and India.

Finally, the Thailand-Chile Free Trade Agreement, does not include an ISDS provision. The other FTAs to which Thailand is party are goods only and hence do not have an investment chapter.

Ewing-Chow (2016) has researched the impact of ISDS provisions and found that there were only 27 cases against ASEAN members and that most were related to BITs rather than FTAs (see Table 1). In fact, he noted that only two of the cases have resulted in awards against the host state. He argues that, in this case, the negative impact of ISDS is overrated.

Table 1. ASEAN: Number of Known ISDS Cases 1981-2016.

\begin{tabular}{|l|c|c|}
\hline No. & Country & No. of Cases \\
\hline 1 & Indonesia & 9 \\
\hline 2 & Vietnam & 7 \\
\hline 3 & Philippines & 4 \\
\hline 4 & Malaysia & 2 \\
\hline 5 & Lao & 1 \\
\hline 6 & Cambodia & 1 \\
\hline 7 & Thailand & 1 \\
\hline 8 & Myanmar & $\mathbf{2 7}$ \\
\hline
\end{tabular}

Source: Ewing-Chow 2016. 


\section{Methodology}

The research uses the narrative/case study approach to examine the impact of international trade rules on investor-state dispute settlement processes. In particular it analyzes the Walter Bau Case to ascertain what lessons can be learnt from this particular international arbitration case.

\section{The Walter Bau Case}

Walter Bau AG (in liquidation) (Walter Bau) purchased shares in Don Muang Tollway Co. Ltd., a Thai company. In 1989 Walter Bau entered into a concession agreement to design, construct, operate and maintain the Don Muang Tollway for the right to collect tolls for 25 years (Mangklatanakul 2010: 81). In 2005 Walter Bau filed an arbitration case under the ThailandGermany BIT (2002) against the Thai Government alleging the lack of Fair and Equitable Treatment (FET) in relation to its investment. It claimed that Thailand refused to allow an increase in tolls based on an amended concession contract. ${ }^{2}$ The Thai government reduced tolls in 2004 and continued to improve roads in the vicinity of the toll road which affected traffic volumes and subsequent closed of Don Muang International Airport in 2007 (Mangklatanakul 2010).

Arbitral proceedings were conducted in Switzerland (Walter Bau AG (in liquidation) v Kingdom of Thailand (Award) 2009). The Tribunal awarded Walter Bau an amount of $€ 29.21$ million due to a breach of the BIT in relation to the provision for fair and equitable treatment (Kläger 2014: 142). The Thai Government declined to settle so Walter Bau took enforcement action in New York and received a final judgement for the payment of the award (Schneider $\mathrm{v}$ Kingdom of Thailand, 2011). Thailand gave notice of appeal to the Circuit Appeals Court but lost the appeal (Schneider v Kingdom of Thailand 2012). Thailand then challenged the award in Germany. In a decision dated 30 January 2013, the Federal Court of Justice ruled

"that a state party may rely on the defence of sovereign immunity in proceedings to declare an award enforceable where the arbitral tribunal had erroneously assumed Jurisdiction under a bilateral investment treaty (BIT), making such an award non-binding for the state party." (Wilske and Krapfl 2013).

The Federal Court of Justice resubmitted the case to the Higher Regional Court of Berlin to determine whether sovereign immunity applied in this case and the Berlin court reaffirmed that it did not and that the award in favor of the insolvency administrator was enforceable (Wilske et al. 2015). Kroll (2013) convincingly argues that if a state party continues to participate in the arbitration and to defend on the merits it should be precluded from using its immunity defense in enforcement proceedings.

\footnotetext{
${ }^{2}$ The Germany Thailand BIT of 2002 replaced an earlier BIT signed in 1961.
} 
The most comprehensive description of the arbitration with its twists and turns appears to have been published by Tanielian (2012). The issue of sovereign immunity in this case has been discussed extensively by Center for Transnational Litigation and Commercial Law (2013).

In July 2009, as a result of the Walter Bau arbitration, the Thai Cabinet resolved that all public-sector contracts made in Thailand or overseas should not contain an arbitration clause except on a case by case Cabinet dispensation (Sucharitkul 2015: 313). The Cabinet rationale was that when large projects or concessions are submitted to arbitration government agencies tend to lose the case or are found liable to pay compensation (Sucharitkul 2015: 313).

One Thai legal commentator wrote:

"The bitter and protracted sagas of Hopewell and Walter Bau reinforce the notion that an award is only worth the paper it is written on until it has been fulfilled or enforced. Winning an arbitration award against the Thai government is merely the start of what is likely to be a long drawn-out judicial battle." (Sucharitkul 2015: 314).

Kläger (2014: 184) concluded that complex multi-jurisdictional disputes, like that of Walter Bau, as "a necessary result of the frequently invoked proliferation and fragmentation of international dispute settlement fora".

The available literature tends to focus on the arbitration and legal processes.

\section{Administrative Pitfalls}

According to Mangklatanakul (2010), writing when she was the Thai Director of the International Law Division, Department of Treaties and Legal Affairs of the Ministry of Foreign Affairs, identified pitfalls in the pre-dispute, dispute and post-dispute phases of the dispute management. Firstly, Government officials were not fully aware of the legal implications of the treaty and the realization that an investor could invoke ISDS (p. 82). The Government was unaware that their decisions could invoke action under the International Investment Agreements (IIAs) and presumably lacked access to expert advice on this issue. Secondly, there should be a lead agency specializing in dispute management (p. 82). Thailand's dispute management was hampered by the lack of a lead agency which could assemble all of the facts, prepare the case and consider options for settlement (p. 82). This was compounded by a lack of perspective and experience of investment treaty arbitration ( $\mathrm{p} 82$ ). There was also a language barrier which required translation which caused delay, costs and inaccuracy (p. 82). There were also political costs as it could be perceived that the State failed to protect the public interest by granting concessions to a foreign entity (p. 83).

Post-dispute Thailand did not accept the arbitration award because of the potential political costs due to Thai public opinion and, therefore, continued to fight its case rather than settle (p. 83). A further barrier to settlement was the potential for personal liability under the Liability of Officials Act BE 2539, officials may be held to breach of official duties in handling Investor-State disputes (p. 82). 


\section{Findings/Results}

Walter Bau provides a significant lesson for government's developing PPP projects which can have multiple investors at both the construction and operation stages. These investors are often foreign companies who have no other interest other than their return on capital from their investment while the Thai government had to consider the public interest. Also the government at the time of the dispute was running a campaign to ensure continuing by enacting populist policies. Without going into the merits of the case, the Don Muang (sic) Tollway Project was negatively impacted, or had the potential to be impacted, by subsequent planning decisions. These included traffic management on the existing road corridor, the development of an alternative airport with the initial closure and then down grading of Don Mueang (sic) International Airport, and the proposed freeway on the Hopewell Project, since abandoned, on the adjacent rail corridor. In addition, the definition of a covered investment was not clear as far as the Thai government was concerned; their view being that it could only be covered if it was agreed in writing Mangklatanakul (2010). Art 8 of the ThailandGermany BIT, 2002 states:

"This Treaty shall also apply to approved investments made prior to its entry into force by investors of either Contracting Party in the territory of the other Contraction Party consistent with the latter's laws and regulations."

Clearly the wording of art 8 leaves room for legal argument.

It has even been argued that the current (2017) construction of alternative transportation modes such as the MRT Red-line adjacent to the toll road could be subject to future action as it could further erode the income of the concessionaire (Kokkaew et al. 2015).

Should government policy be subject unreservedly to ISDS under an FTA or BIT? If the government is responsible for the well-being of its citizens, then clearly the priority should be to their well-being. If this affects the operation of Multi-National Corporations (MNCs) then limits may need to be put on their operations provided, of course, that international and domestic companies receive non-discriminatory just and equitable treatment. As will be seen in the next section there has been a shift in policy as can be seen by in the evolution of ISDS provisions which occurred from 2005 to 2010 and beyond.

\section{Discussion}

\section{Implications for Thailand}

The above discussion on ISDS raises issues for Thailand. The first issue: should Thailand sign any treaty that includes an ISDS clause? If yes, should it be qualified? Developing countries in the past have tended to enter into more Bilateral Investment Treaties than developed countries to encourage foreign 
investment. For instance, at 30 November 2017, Thailand had 39 bilateral investments treaties in force whilst Australia, for instance, had 17 (United Nations Conference on Trade and Development 2017. The Thailand-Australia Free Trade Agreement (TAFTA) is a small part of that picture, particularly with Thailand considering a number of new Free Trade Agreements as well as negotiating the Regional Comprehensive Economic Partnership which will be a comprehensive FTA between ASEAN and its current FTA partners: Australia, China, India, Japan, Korea and New Zealand. Thailand needs to press for consistency in the dispute settlement clauses, especially ISDS requirements otherwise the treaties may become unmanageable with different versions of similar clauses. If they do include ISDS, Thailand should also partner in the push for harmonization of such ISDS clauses in international forums such as WTO.

Up until late 2017 there had been no trade disputes between Thailand and Australia since TAFTA was signed. Both parties have utilized the consultation process that is well documented in TAFTA especially in relation to Sanitary and Phytosanitary (SPS) requirements and food standards. While Thailand is an active member of the WTO and has effectively used the WTO Dispute Settlement Understanding mechanism, it was clearly unprepared for arbitration under an Investor State Dispute Settlement mechanism. It would appear that it entered into bilateral investment treaties with the hope that there would be no actions. There is a need for Thailand to review its treaties and ensure that it has a highly skilled secretariat that can take the lead in handling such treaty issues. At the more basic level Thai officials must ensure that contracts are administered in a fair and reasonable manner. If that had been the case it is likely that Walter Bau would have been resolved without the need to invoke the BIT.

In November 2017 notice was given of proposed arbitration under the ISDS provisions (art 917) of TAFTA (Kingsgate 2017: 1). The basis of the claim is that notice was given in May 2016 that a gold mining lease operated by a $100 \%$ Australian owned Thai subsidiary would only be extended until December 2016 at which time the mine was to be closed (Kingsgate 2017: 3). On 16 December 2016 the Thai Prime Minister issued an order under s 44 of the interim Constitution ${ }^{3}$ suspending all gold mining related activities in Thailand from 31 December 2016 (Kingsgate 2017: 3). The company's claim is that had a covered investment under TAFTA and that it did not receive fair and equitable treatment (art 919), its property was unlawfully expropriated (art 912); and its

\footnotetext{
${ }^{3}$ Constitution of the Kingdom of Thailand (Interim), B.E. 2557 (2014) Section 44 states: "In the case where the Head of the National Council for Peace and Order is of opinion that it is necessary for the benefit of reform in any field and to strengthen public unity and harmony, or for the prevention, disruption or suppression of any act which undermines public peace and order or national security, the Monarchy, national economics or administration of State affairs, whether that act emerges inside or outside the Kingdom, the Head of the National Council for Peace and Order shall have the powers to make any order to disrupt or suppress regardless of the legislative, executive or judicial force of that order. In this case, that order, act or any performance in accordance with that order is deemed to be legal, constitutional and conclusive, and it shall be reported to the National Legislative Assembly and the Prime Minister without delay." [unofficial translation].
} 
investment was impaired as it did not receive Most Favored Nation Treatment as required under TAFTA (art 907).

Thailand has learnt from its unfortunate Walter Bau experience. In November the Permanent Secretary of Department of Industry noted that the government had earlier appointed a multi-agency committee to negotiate with Kingsgate to settle the dispute in the country's best interests and taking all stakeholders' interests into account (Nation 2017). Most importantly he advised that the government was prepared to settle the dispute under the international arbitration process as sought by Kingsgate. He acknowledged that the process was in accordance with the bi-lateral agreement with Australia (i.e. TAFTA).

\section{Wider Implications}

The lessons from the Walter Bau case should be carefully considered by both developing and developed economies. The issue is not that investors should be reimbursed for actions that do not provide fair and equitable treatment it is rather the wider impacts that are of concern.

The decision of the Thai government to reduce the tolls on the Don Muang Expressway should have resulted in restitution by the Thai government. Rather, it is the other parts of the claim that are of concern. Whilst it was not explicitly considered, as such, during the arbitration, the claim also stated there was significant impact as the government continued to improve roads in the vicinity of the toll road and the subsequent closure of Don Muang Airport in 2007 which also significantly impacted traffic volumes As noted above there has also been speculation that the MRT Red-line being constructed adjacent to the toll road could be subject to future action as it could further erode the income of the concessionaire.

The implications are that without suitable protections an Investor could use the ISDS provision to thwart sound planning decisions. Traffic congestion in Bangkok is a major issue. Should an Investor be able to hinder the government from easing that congestion by improving other roads in the vicinity and providing other transport modes and in the process reducing the production of greenhouse gases? Should it facilitate an action that prevents a government from relocating an airport as the current airport had exceeded its operating capacity? For the authors the answers to these questions are a resounding no.

Clearly, the use of retrospective legal measures should be ruled out. There is a need, however, to develop a suitable strategy for current BITs and FTAs.

As international investors, such as superannuation funds, invest in PPP infrastructure projects such as toll-roads this leaves the host government open to possible action. It is doubtful if a lot of the decision makers are even aware that their actions might be impacted by a bilateral investment treaty or an FTA. Thailand is not on its own in that regard. In fact, many of these decisions are at the state or local level whereas treaties are under the purview of the central government. 
The first action required is the need to increase awareness at all levels of government concerning obligations under international treaties and ensure that advice is sought before making decisions that might have far reaching implications.

Every party should be ensured of just and equitable treatment regardless of whether they are domestic or international. Care needs to be taken that the required levels of service are provided in contracts and the risk is allocated to the party best able to manage that risk. For instance, in the Walter Bau case the traffic risk should have been borne by the government with the concession agreement clearly providing compensation for reduced traffic volumes. Onthe-other-hand windfall profits should be shared with the government. Often an investor was not a party to the original contract. This is not unusual as the original concession holders sell down their interest once the project has entered its operational phase. If these issues are clearly understood the drafting of an appropriate concession agreement is fairly straight forward. The task should be undertaken by well qualified and experienced specialist lawyers and not the inhouse legal team.

Clearly there is now a greater understanding by ASEAN and governments around the world that current ISDS clauses did not protect them from action for sound policy decisions that were in the interests of their citizens in relation to areas such as the environment, health, safety, cultural heritage and security. Hence the more detailed clauses included in the ASEAN FTAs negotiated around 2009 and beyond.

BITs and FTAs should be reviewed and if possible negotiated to include such ISDS provisions. Some developed countries such as Australia have not accepted an ISDS provision in an FTA. Australia took such action when it was negotiating the Australia-United States Free Trade Agreement (AUSFTA).

Most importantly the rules for ISDS must be clearly laid out and the arbitration process transparent and the decisions made public.

The other issue that must be addressed is the capacity of a party to negotiate an FTA or even a BIT. Thailand has considerable experience in FTA negotiation as does ASEAN. Many developing countries do not and require capacity building and the use of external resources. This is not just an issue for developing countries. As the United Kingdom prepares to leave the European Union and negotiate its own FTAs it has found that it lacks both the capacity and capability to undertake that task and has sourced specialists from around the world (Reuters Staff 2017).

All this really shows that an interconnected world requires interconnected solutions. Surely an enhanced role for the World Trade Organization!

\section{Conclusion}

It is beholden on developing and developed economies alike to ensure that key stakeholders are aware of the possible ramifications from their decisions especially where they might be impacted by ISDS clauses in BITs, IIAs and FTAs. All actions must be fair and equitable. 
It is also incumbent on countries to review their treaties and ensure that the clauses are well understood and renegotiate them where necessary.

There also needs to be greater awareness by politicians and officials that the obligations in international treaties are enforceable despite and cannot be overturned by populist political actions.

Should a dispute arise the Thai example shows the need for the Government to appoint a key agency as the lead agency to coordinate and prepare responses; and seek expert advice and investigate possible settlement scenarios.

\section{References}

Agreement Establishing the ASEAN-Australia-New Zealand Free Trade Area (AANZFTA) signed February 27, 2009 (entered into force July 1, 2009) [2010] ATS 1.

Agreement on Investment of the Framework Agreement on Comprehensive Economic Cooperation between the People's Republic of China and the Association of Southeast Asian Nations signed August 15, 2009 (entered into force January 1, 2010).

Agreement of Investment under the Framework Agreement on Comprehensive Economic Cooperation among the Governments of the Member Countries of the Association of Southeast Asian Nations and the Republic of Korea, signed June 2, 2009 (entered into force September 2009).

Agreement on Investment under the Framework Agreement on Comprehensive Economic Cooperation between the Association of Southeast Asian Nations and the Republic of India signed November 12, 2014 (not yet in force).

ASEAN Comprehensive Investment Agreement, signed February 26, 2009 (entered into force February 24, 2012).

Asian Development Bank. 2000. Developing Best Practice for Promoting Private Sector Investment: Roads.

Australia-US Free Trade Agreement (AUSFTA), signed 18 May 2004 (entered into force 1 January 2005) [2005] ATS 1.

Center for Transnational Litigation and Commercial Law (2013) Sovereign Immunity in Enforcement Proceedings - The decision of the German Supreme Court in Walter Bau vs. Government of Thailand. Transnational Notes (Center for Transnational Litigation and Commercial Law, New York University School of Law, April 5, 2013). Available at: http://bit.ly/2G9WGNH.

Constitution of the Kingdom of Thailand (Interim), B.E. 2557 (2014).

Ewing-Chow M (2016) Reforming the IIA System: Investment Arbitration in AsiaPacific and ASEAN. PowerPoint Presentation in Proceedings of Regional Seminar on IIAs and Sustainable Development, and 6th Meeting of the Asia-Pacific FDI Network (Bangkok, Thailand, December 1-2, 2016). Available at: http:// http:// bit.ly/2Iajmha.

Japan Thailand Economic Partnership Agreement, signed 3 April 2007 (entered into force 1 November 2007).

Kingsgate Consolidated Limited (2017) Update on Legal Proceedings re Chatree Gold Mine, Thailand. Public Release via ASX online, 10 November 2017. Available at: http://www.asx.com.au/asxpdf/20171110/pdf/43p3tbzmrgdhk4.pdf.

Kläger R (2014) Werner Schneider (liquidator of Walter Bau AG) v Kingdom of Thailand: sovereign immunity in recognition and enforcement proceedings under German law. ICSID Review 29(1): 142-148. 
Kokkaew N, Oliveira Cruz C, Alexander D (2015) The Impact of Rule of Laws on the Recovery of Distressed PPP Infrastructure Projects. Munich Personal RePEc Archive. Paper 77494 (June 1, 2015). Available at: https://mpra.ub.uni-muenchen. de/77494/.

Kroll S (2013) Sovereign Immunity in Enforcement Proceedings - The decision of the German Supreme Court in Walter Bau vs. Government of Thailand. Center for Transnational Litigation and Commercial Law, New York University, Transnational Notes, (April 5, 2013). Available at: http://bit.ly/2G9WGNH.

Liability of Officials Act BE 2539 (1996). [Thailand].

Mangklatanakul V (2010) Thailand's First Treaty Arbitration: Gain from Pain. In Proceedings of the Washington and Lee University and UNCTAD Joint Symposium on International Investment and Alternative Dispute Resolution, in (Lexington Va. March 29, 2010) 81-86. Available at: http://bit.ly/2oV7uqy.

Nation (2017) Thailand faces uphill fight over gold mine closure. The Nation (online, November 4, 2017). Available at: http://bit.ly/2oU2t2p.

Reuters Staff (2017) UK's 'copy and paste' trade policy forced by lack of negotiating capacity - official. Reuters (online), September 5, 2017. Retrieved from: http://re ut.rs/2p0sg8b. [Accessed 9 December 2017).

Sappideen R, He L (2012) Investor-state arbitration: the roadmap from the multilateral agreement on investment to the transpacific partnership agreement. Federal Law Review 40(2): 207 - 227.

Schneider $v$ Kingdom of Thailand (USCA $2^{\text {nd }}$ Cir, (11-1458-cv), Decision, August 8, 2012).

Schneider $v$ Kingdom of Thailand (USDC SDNY, 10 Civ. 2729 (DAB) Confirmation of Arbitral Award, March 14, 2011).

Sucharitkul V (2015) From Walter Bau to Hopewell: pathways to Bangkok Don Muang Airport. Asia-Pacific Arbitration Reporter 1: 309-315.

Tanielian A (2012) German court authorizes seizure of Thai Prince's plane in pursuit of arbitral award: Walter Bau AG v. Kingdom of Thailand. Journal of Legal Affairs and Dispute Resolution in Engineering and Construction 4(3): 1-13. DOI=http:// doi.acm.org/10.1061/(ASCE)LA.1943-4170.0000093.

Treaty between the Kingdom of Thailand and the Federal Republic of Germany concerning the Encouragement and Reciprocal Protection of Investments, signed June 24, 2002 (entered into force October 20, 2004).

Thailand-Australia Free Trade Agreement (TAFTA) signed 5 July 2004 (entered into force 1 January 2005) [2005] ATS 2.

Thailand-Chile Free Trade Agreement, signed 4 October 2013 (entered into force 5 November 2015).

Thailand New Zealand Closer Economic Partnership Agreement, signed 19 April 2005 (entered into force 1 July 2005).

United Nations Conference on Trade and Development, Investment Policy Hub, International Investment Agreements. Retrieved from: http://bit.ly/2FjY7Mi. [Accessed 9 December 2017].

Walter Bau AG (in liquidation) v Kingdom of Thailand (Award) (Arbitral Tribunal, July 1, 2009).

Wilkins G (2014) Trade Treaties expose Australia to costly litigation, experts warn, Sydney Morning Herald, (online) August 30, 2014. Available at: http://bit.ly/2F kjFYR. 
Wilske S, Krapfl C (2013) German Federal Court of Justice on sovereign immunity in enforcement proceedings. Practical Law, (online February 28, 2013). Available at: http://us.practicallaw.com/3-524-4398.

Wilske S, Krapfl C, Lutz G (2015) Higher Regional Court of Berlin denies sovereign immunity objection in enforcement proceedings. Practical Law, (online April 7, 2015). Available at: http://uk.practicallaw.com/3-607-9910.

World Bank \& Ministry of Construction, Japan (1999a) Asian Toll Road Development Program: Review of Recent Toll Road Experience in Selected Countries. Available at: http://www.worldbank.org/transport/roads/tr_docs/padeco/toc.htm.

World Bank \& Ministry of Construction, Japan (1999b) Preliminary Tool Kit for Toll Road Development: Draft Final Report, May 1999, III-132. Available at: http:// www.worldbank.org/transport/roads/tr_docs/padeco/toc.htm. 
